Journal of Sustainability Perspectives

\title{
Current Scenario of Environmental Pollution \& Its Solution by Plantation In Changing Climate
}

\author{
Muhammad Kabir ${ }^{1,}$, Um e Habiba ${ }^{2}$, Zia-Ur-Rehman Farooqi ${ }^{3}$ \\ ${ }^{1}$ Department of Biological Sciences, University of Sargodha, Sub-Campus Bhakkar, Pakistan \\ ${ }^{2}$ Department of Physics, Riphah International Universit, Faisalabad Campus \\ ${ }^{3}$ Department of Botany, University of Karachi, Karachi, 75270, Pakistan \\ * corresponding author: muhammad.kabir@uos.edu.pk
}

Article Info

Received:

15 March 2021

Accepted:

25 May 2021

Published:

1 August 2021

DOI:

Presented in The $6^{\text {th }}$ International (Virtual) Workshop on UI GreenMetric World University Rankings (IWGM 2020)

\begin{abstract}
Life's quality is depending on quality of environment. As environment creates favorable surroundings for survival, growth and development of existing organisms. All living organisms are affected indirectly or directly due to environmental pollution. It is due to rapid increases in human being. Environmental pollution especially by anthropogenic activities is a main problem facing the world today and there is a need for increasing attentiveness that a clean and green environment is essential for better growth of living organisms in this changing climate of World. It is our top most priority to keep our country clean and green as cleanness is a part of our faith. Thus environmental pollution is causing great threat to plants, animals and to human all over the world. As each and every problem has a solution, because problem is always artificial, man desires to find the solution. In recent innovations there is a need to develop clean and green spaces within and around the polluted areas for existence of better environment. As some plants can act as pollution sink working as natural lungs. So, "the green revolution (Plantation) is the best solution to arrest the pollution". If haphazard population growth goes on increasing without realizing the importance of trees especially those which act as pollution sink then there would be more critical changes for living organisms in near coming future.
\end{abstract}

\section{Keyword:}

Anthropogenic activities, Environmental pollution, Green revolution, Natural lungs, Plantation.

\section{Introduction}

International concern has grown about anthropogenic climate change. Because climate change is one of the most important problem on a global scale in recent years. Due to rapid increase in green house gase emissions including carbondioxide $\left(\mathrm{CO}_{2}\right)$, methane $\left(\mathrm{CH}_{4}\right)$ and nitrogen monoxide $\left(\mathrm{NO}_{2}\right)$, which are released into atmosphere as a result of human activities such as industrialization, urbanization, transportation, population explusion, fossil fuel consumption, agricultural activities and energy production, a significant 
rise in the average temperature of the earth's surface has been observed. According to data of 2016 obtained from NASA (National Aeronautics and Space Administration). The average global temperature on Earth's surface is increasing by about $0.8^{\circ} \mathrm{C}$ since 1880 . Tree planting is one of the effective ways to alleviate air pollution problems in urban areas. However, in some situations, air pollutants are often present at high concentration due to the combined effects of building geometries and roadside trees. Phytoremediation is a process of absoprtion of pollutants by different plant species to reduce harmful effects of toxic pollutants in the environments and rendering the environment as clean and green space for existence of life. In present study Cassia fistula L. is selected for this purpose.

Environmental pollution is a key concern that has been influencing health of living organisms, including plants, animals as well as all components of environment i.e. air, water and soil. Local environmental and health related organizations are regularly making daily pollution predictions for public consciousness and for use in making conclusion relating to reduction methods in addition to the regulation of environmental quality. Phytoremediation is one of the most effective methods in this regard.

The meting down of polar ice-caps resulting due to climate change is a natural phenomenon but necessary exercise for maintaining the natural balance like reduction of ozone layer is now recovering during Covid-19. Pollution is looking a big issue from all sided of World and is also responsible for big tension. The main cause of pollution on the surface of earth is man himself.

Man is continuously uses the natural resources and is not responsible for the consequences. Man is so selfish that he can go to the last extent for the utilization of natural resources doesn't think for other species like bacteria, fungi, plants and animals [1]. Man is destroying to all these living organisms by destroying their habitat. Man also drives out the natural resources from all these other species existing of the surface of earth which they use for their existence. As a result of these selfish activities every year humen are detecting a new bacteria and viruses or other pathogenic organisms which are producing ill effects on the health of human, or simply we can say that they are producing different illness in the human population.

Scientists always say that they have exposed some new types of bacteria or viruses or other living organisms, they claim that they are totally new, but in real practice nobody is new on the surface of earth, basically there is alteration in the living style of an organism, or there may be some type of resistance by a specific type of species for a favourable environmental conditions. All those species which could be affected by the humen in one way or another way, they basically alter themselves, and proceed towards humen in a unusual way and then show their poor behavior for man, so it is only humen who had fascinated all types of natural resources from the alarmed species which they are using for the existence of their life [1].

Cassia fistula L. commonly known as golden shower tree which is national flower of Thailand belongs to kingdom plantae, division spermatophyte, class angiospermae, order fabales, family fabaceae (Legume family). From spring to summer, it produces attractive golden flowers. Cassia is a large genera with about 500 species, which includes a large number of extremely good-looking flowering trees [2]. It has large significance for human society as it has a medium size stem which produce durable wood used for construction purposes. Due to its shaded character this plant species is grown along roadsides and parks. It is successfully established in an extensive range of soil, environmental and climatic conditions such as pollution stress. The different parts of plants are being used in folk 
medication for cancer of the throat, abdomen, liver, glands and stomach. Sweetish pulp around the seed is used as mild laxative.

Although the environmental pollutants produced from anthropogenic activities in Pakistan have been analyzed by some investigators, almost no attempt had been made to evaluate the effects of different environmental pollutants on soil and vegetation and their uptake by plantation, as their role of pollution sink. In this investigation the effects of toxic pollutants from different industries on seedling growth of $C$. fistula were investigated. The findings will provide a basis for the future extensive study in this field of ecology by maintaining natural balance by plantation on surface of earth.

\section{Materials and Methods}

The seed germination and seedling development experiments were done in green house at the Department of Botany, University of Karachi. The vivacious and the same size seeds of Cassia fistula L. were gathered from the plant developing in the Karachi University Campus. The micropyle finishes of seeds were sliced somewhat with scissors to break seed dormancy and seeds were planted in a nursery soil at $1.00 \mathrm{~cm}$ depth in earthen pots and irrigated with tap watered every day. Following fourteen days same size seedlings were relocated in plastic pots of $20 \mathrm{~cm}$ width and $9.8 \mathrm{~cm}$ top to bottom having the soil of Karachi University Campus as control and industrial contaminated soils. There were five replicates for every treatment and the pots were arranged in completely randomized design. One seedling was planted in each pot and the plants were watered normally.

During development pots were rearranged each week. Seedling height, number of leaves, leaf area and plant circumference were noted weekly for eight weeks. After eight weeks, seedlings were taken out from pots, washed their roots with tap water and measured root, shoot and seedlings length, plant circumference, number of leaves and leaf area. The root, shoot and leaves were dried up in an oven at $80^{\circ} \mathrm{C}$ for 24 hours and their oven dried weights were determined. The root/shoot ratio, leaf weight ratio, specific leaf area and leaf area ratio were also determined as described by [3].

Soil samples were obtained from the industrial areas and University Campus at $30 \mathrm{~cm}$ depth. These samples were brought to the laboratory in polythene bags. After air drying soil was passed through $2 \mathrm{~mm}$ sieve. Mechanical analysis of soil samples were carried out by different tests [2]. Tables 1-2 showed the physical and chemical characteristics of different soils [4].

Statistical analysis: Data of different growth parameters were statistically analyzed by Analysis of Variance (ANOVA) and Duncan Multiple Range Test (DMRT) on personal computer at $p<0.05$ level using SPSS version 13 Software package.

\section{Results}

The effects of different industrial pollutants on the seedling growth performance and biomass production of Cassia fistula L. was recorded (Table 1 a \& b). Results of the present study revealed that $C$. fistula was adjusted for its different growth parameters in National Foods Ltd. factory soil as compared to others soils of industrial areas as well as control (Fig. 1 ). Root, shoot and seedling length was significantly $(p<0.05)$ high and recorded as 8.62 , 11.90 and $20.52 \mathrm{~cm}$, respectively for seedlings raised from the soil of National Foods Ltd. factory. For control (University Campus) these parameters was measures as 7.28, 11.22 and $16.94 \mathrm{~cm}$ respectively, while other soil of industrial site had intermediate root, shoot and seedling lengths. 
Plant cover and leaf area were comparatively high in seedlings raised from the soil of industrial areas than the control. Except that of seedlings growing in Indus battery soil all the other had significantly $(p<0.05)$ more plant cover and leaf area as compared to control seedlings. Number of leaves were also significantly $(p<0.05)$ more in industrial areas seedlings except that of Indus battery soil. Principally, Indus battery soil exhibited great reduction in most of the growth parameters as compared to other industrial soil as well as control.

The effects of industrial pollutants on biomass production of $C$. fistula were also observes. Seedling fresh weight showed that healthy seedlings were grown in National Foods Ltd. factory soil as compared to seedlings raised from the soil of other industries as well as control. For National Foods Ltd. factory fresh weight was recorded as $2.76 \mathrm{~g}$ which was reduced to $2.09 \mathrm{~g}$ for control while, other industrial soil showed reduction in this parameters. Fresh weight reduction was more prominent for the seedlings raised from Indus battery soil. Total plant dry weight which comprises on the root, shoot and leaf dry weight was comparatively low in industrial areas soil as compared to control. Root/shoot ratio and leaf weight ratios were also significantly $(p<0.05)$ reduced in industrial soil as compared to University Campus. Specific leaf area and leaf area ration were significantly $(p<0.05)$ reduced in National Foods Ltd. factory, University Campus and Indus battery soil.

Soil analysis of University Campus and industrial areas showed that low maximum water holding capacity was recorded for University Campus as compared to the industrial soil (Table 2 a \& b). High bulk density with low porosity was recorded for Universal Chemicals factory soil. The percentage of $\mathrm{CaCO}_{3}$ (31.65\%) was high in Indus battery soil which decreased to $21.60 \%$ for University Campus while, this percentage of $\mathrm{CaCO}_{3}$ was low in other industrial soil samples. In Haroon Textile factory industry soil chloride contents was determined as $710 \mathrm{mgL}^{-1}$ which was decreased in other industrial soils but chloride contents were not found in Indus battery as well as in University Campus soil. The industrial soils were acidic in nature except National Foods Ltd. factory in which pH was determined as 7.65. Sulphur contents were high in National Foods Ltd. factory along with low electrical conductivity and total dissolved salts. Electrical Conductivity (EC) and Total Dissolved Salt (TDS) were low in industrial samples as compared to University Campus soil except in Indus battery soil.

\section{Discussions}

C. fistula growth showed its dual nature as it was enhanced in tannery effluents but reduced in Indus battery and Universal Chemicals factory soils indicating that different industrial pollutants can affect its growth in some variable way. Tannery pollutants are phyto-extracted by the species but Indus battery and Universal Chemicals factory soils showed their deleterious effects on its growth. C. fistula showed better growth in tannery effluents probably due to mineral elements such as $\mathrm{Al}, \mathrm{Fe}, \mathrm{Ca}, \mathrm{Na}, \mathrm{K}$ and $\mathrm{Si}$ which are generally present in significant quantities in discharged pollutants coming in air, water and soil. These incoming pollutants also resulted in environmental pollution effecting the growth of other plant species. So environmental pollution is an important factor governing seed germination and seedling growth of different plant species. The effects of toxic substances on plants are dependent on the amount of toxic substance taken up from the given environment. Some plants species can act as pollution sink for industrial pollutants as they can tolerate their effects showing great resistance against them. Actually different industries are affecting to different plant species regarding to their morphology as well as 
productivity.

Soil analysis indicated that industrial soil is sandy in nature while, University Campus soil is clay loam. Bulk density of industrial soil was high with less porosity as compared to University Campus soil. Calcium carbonate was high in University Campus as compared to industrial soil. $\mathrm{pH}$ of University Campus soil was 7.00 while industrial soils $\mathrm{pH}$ ranged from acidic to basic with high amount of chlorides in Universal Chemicals factory and Haroon Textile factory. Low electrical conductivity and total dissolved salt also increased the growth of $C$. fistula in some of the variables in industrial soils as compared to University Campus soil. The texture of industrial soils is drastically disturbed due to irregular pilling of wastes materials. Particle size distribution is a major factor in governing successful vegetation on polluted soil as it influences water holding capacity, bulk density, soil moisture availability and nutrient contents as well as availability [5].

This study investigated that physico-chemical parameters of soil such as $\mathrm{pH}$, electrical conductivity, chloride, sodium and potassium, sulphate, electrical conductivity and TDS were relatively high in the industrial area soil and severely affected seed germination and seedling growth in Indus battery and Universal Chemicals factory soils. The Indus battery effluent could possibly lead to soil deterioration and low productivity. Terrestrial and aquatic environment pollution could be averted by proper treatment of the effluents using suitable conventional methods.

From the present investigations it was observed that God is great, as He maintained balance for biosphere, by all the ways. It is also important to mentioned that sometimes their occurs natural disasters such as cyclones or drought, earthquakes, volcanoes, and most recently occurred Covid-19 etc., enlisted all phenomenons in one or another way are making the balance on the surface of Earth. The destructive of natural phenomenons take place when the unwanted substances such as pollution reaches at its extreme. So the man should be alert and prepared to face the harms related with these harmful pollutants resulted from anthropogenic activities. One act which man can do to stop adding unwanted substances to the environment are simply to find other ways which could do the job in place of materials which are destructive for the environment. Secondly human should try to find the processes, techniques and tools and the reactions which may possibly come together with the pollutants and can convert the pollutants into useful substances, which are imposing less ill effects on the environment.

\section{Conclusion}

The conclusion which could be drawn from this study is that the growth of $C$. fistula was high in National Foods Ltd. factory soil as compared to other industrial and University Campus soils. Therefore this species should be given preference to be planted around the Foods processing industries due to its tolerance against the pollutants. It is recommended that other plant species showing their tolerance for other industrial pollutants must be selected to reduce environmental pollution. 
Table 1 (a). Growth of Cassia fistula in soils of different areas

\begin{tabular}{cccccccc}
\hline Treatments & $\begin{array}{c}\text { Root } \\
\text { length } \\
{[\mathbf{c m}]}\end{array}$ & $\begin{array}{c}\text { Shoot length } \\
{[\mathbf{c m}]}\end{array}$ & $\begin{array}{c}\text { Seedling } \\
\text { length } \\
{[\mathbf{c m}]}\end{array}$ & $\begin{array}{c}\text { Plant cover } \\
{[\mathbf{c m}]}\end{array}$ & $\begin{array}{c}\text { Number of } \\
\text { leaves }\end{array}$ & $\begin{array}{c}\text { Leaf area } \\
{[\mathrm{Sq} \mathbf{c m}]}\end{array}$ & $\begin{array}{c}\text { Seedling } \\
\text { fresh } \\
\text { weight [g] }\end{array}$ \\
\hline A & $7.28 \pm 0.19 \mathrm{~b}$ & $11.22 \pm 0.43 \mathrm{ab}$ & $16.94 \pm 0.52 \mathrm{~b}$ & $33.84 \pm 2.39 \mathrm{c}$ & $11.00 \pm 0.45 \mathrm{c}$ & $4.71 \pm 0.37 \mathrm{c}$ & $2.09 \pm 0.30 \mathrm{~b}$ \\
B & $5.22 \pm 0.63 \mathrm{c}$ & $8.26 \pm 0.26 \mathrm{c}$ & $12.90 \pm 0.25 \mathrm{c}$ & $25.60 \pm 1.55 \mathrm{~d}$ & $10.00 \pm 0.63 \mathrm{c}$ & $2.54 \pm 0.36 \mathrm{~d}$ & $0.92 \pm 0.06 \mathrm{c}$ \\
C & $4.08 \pm 0.26 \mathrm{~d}$ & $8.84 \pm 0.32 \mathrm{c}$ & $12.92 \pm 0.57 \mathrm{c}$ & $37.42 \pm 2.19 \mathrm{c}$ & $11.66 \pm 1.03 \mathrm{c}$ & $6.40 \pm 0.17 \mathrm{~b}$ & $1.06 \pm 0.03 \mathrm{c}$ \\
D & $5.56 \pm 0.28 \mathrm{c}$ & $10.52 \pm 0.48 \mathrm{~b}$ & $16.08 \pm 0.70 \mathrm{~b}$ & $44.98 \pm 1.59 \mathrm{~b}$ & $16.00 \pm 1.52 \mathrm{~b}$ & $9.40 \pm 0.67 \mathrm{a}$ & $1.84 \pm 0.08 \mathrm{~b}$ \\
E & $8.62 \pm 0.23 \mathrm{a}$ & $11.90 \pm 0.47 \mathrm{a}$ & $20.52 \pm 0.64 \mathrm{a}$ & $55.86 \pm 2.03 \mathrm{a}$ & $20.20 \pm 0.37 \mathrm{a}$ & $10.21 \pm 0.89 \mathrm{a}$ & $2.76 \pm 0.16 \mathrm{a}$ \\
\hline L.S.D. & $\mathbf{1 . 0 5}$ & $\mathbf{1 . 1 8}$ & $\mathbf{1 . 6 5}$ & $\mathbf{5 . 8 4}$ & $\mathbf{2 . 6 7}$ & $\mathbf{1 . 6 4}$ & $\mathbf{0 . 4 8}$ \\
(p<0.05) & & & & & & & \\
\hline
\end{tabular}

Table 1 (b). Dry weights and ratios of different variables of Cassia fistula in soils of different areas

\begin{tabular}{|c|c|c|c|c|c|c|c|c|}
\hline $\begin{array}{c}\text { Treatment } \\
\text { s }\end{array}$ & $\begin{array}{c}\text { Root dry } \\
\text { Weight [g] }\end{array}$ & $\begin{array}{l}\text { Shoot dry } \\
\text { weight [g] }\end{array}$ & $\begin{array}{c}\text { Leaf dry } \\
\text { weight } \\
\text { [g] }\end{array}$ & $\begin{array}{c}\text { Total plant } \\
\text { dry weight } \\
{[\mathrm{g}]}\end{array}$ & $\begin{array}{c}\text { Root/Sho } \\
\text { ot } \\
\text { ratio }\end{array}$ & $\begin{array}{c}\text { Leaf } \\
\text { weight } \\
\text { ratio }\end{array}$ & $\begin{array}{l}\text { Specific } \\
\text { leaf area } \\
{\left[\mathrm{cm}^{2} \mathrm{~g}^{-1}\right]}\end{array}$ & $\begin{array}{c}\text { Leaf area } \\
\text { ratio } \\
{\left[\mathrm{cm}^{2} \mathrm{~g}^{-1}\right]}\end{array}$ \\
\hline A & $\begin{array}{c}0.34 \pm 0.03 \\
b\end{array}$ & $\begin{array}{c}0.16 \pm 0.18 \\
\text { cd }\end{array}$ & $\begin{array}{c}0.44 \pm 0.0 \\
6 b\end{array}$ & $\begin{array}{c}0.93 \pm 0.11 \\
a\end{array}$ & $\begin{array}{c}2.12 \pm 0.1 \\
0 a\end{array}$ & $\begin{array}{c}0.47 \pm 0.0 \\
2 a\end{array}$ & $\begin{array}{c}11.26 \pm 1 \\
12 b\end{array}$ & $\begin{array}{c}5.28 \pm 0.45 \\
b\end{array}$ \\
\hline B & $\begin{array}{c}0.12 \pm 0.00 \\
7 d\end{array}$ & $\begin{array}{c}0.12 \pm 0.00 \\
7 d\end{array}$ & $\begin{array}{c}0.17 \pm 0.0 \\
3 c\end{array}$ & $\begin{array}{c}0.41 \pm 0.02 \\
\mathrm{c}\end{array}$ & $\begin{array}{c}1.00 \pm 0.1 \\
6 b c\end{array}$ & $\begin{array}{c}0.40 \pm 0.0 \\
4 a b\end{array}$ & $\begin{array}{c}15.48 \pm 1 \\
90 \mathrm{~b}\end{array}$ & $\begin{array}{c}6.12 \pm 0.71 \\
b\end{array}$ \\
\hline C & $\begin{array}{c}0.14 \pm 0.03 \\
\mathrm{~cd}\end{array}$ & $\begin{array}{c}0.23 \pm 0.02 \\
b\end{array}$ & $\begin{array}{c}0.19 \pm 0.0 \\
2 c\end{array}$ & $\begin{array}{c}0.56 \pm 0.06 \\
b c\end{array}$ & $\begin{array}{c}0.61 \pm 0.0 \\
7 d\end{array}$ & $\begin{array}{c}0.34 \pm 0.0 \\
2 b\end{array}$ & $\begin{array}{c}35.28 \pm 4 \\
30 a\end{array}$ & $\begin{array}{c}11.95 \pm 1.3 \\
8 a\end{array}$ \\
\hline D & $\begin{array}{c}0.22 \pm 0.02 \\
c\end{array}$ & $\begin{array}{c}0.22 \pm 0.01 \\
\text { bc }\end{array}$ & $\begin{array}{c}0.26 \pm 0.0 \\
2 c\end{array}$ & $\begin{array}{c}0.70 \pm 0.04 \\
a b c\end{array}$ & $\begin{array}{c}1.00 \pm 0.0 \\
5 c\end{array}$ & $\begin{array}{c}0.38 \pm 0.0 \\
2 b\end{array}$ & $\begin{array}{c}36.21 \pm 2 \\
97 a\end{array}$ & $\begin{array}{c}13.54 \pm 0.6 \\
6 a\end{array}$ \\
\hline$E$ & $\begin{array}{c}0.43 \pm 0.03 \\
a\end{array}$ & $\begin{array}{c}0.33 \pm 0.03 \\
a\end{array}$ & $\begin{array}{c}0.70 \pm 0.0 \\
4 a\end{array}$ & $\begin{array}{c}1.46 \pm 0.01 \\
6 a b\end{array}$ & $\begin{array}{c}1.30 \pm 0.0 \\
7 \mathrm{~b}\end{array}$ & $\begin{array}{c}0.48 \pm 0.0 \\
1 \mathrm{a}\end{array}$ & $\begin{array}{c}14.96 \pm 1 \\
71 b\end{array}$ & $\begin{array}{c}7.16 \pm 0.84 \\
b\end{array}$ \\
\hline $\begin{array}{c}\text { L.S.D. } \\
(p<0.05)\end{array}$ & 0.07 & 0.06 & 0.11 & 0.28 & 0.29 & 0.07 & 7.83 & 2.55 \\
\hline
\end{tabular}

Table 2 (a). Physical characteristics of different soils

\begin{tabular}{|c|c|c|c|c|c|c|c|c|}
\hline $\begin{array}{c}\text { S.N } \\
0\end{array}$ & $\begin{array}{c}\text { Localit } \\
y\end{array}$ & $\begin{array}{l}\text { M.W.H.C. } \\
\text { [\%] }\end{array}$ & $\begin{array}{c}\text { B.D. [gcc } \\
{ }_{1}{ }^{-}\end{array}$ & $\begin{array}{c}\text { Porosity } \\
\text { [\%] }\end{array}$ & Sand [\%] & Silt [\%] & Clay [\%] & $\begin{array}{l}\text { Soil texture } \\
\text { class }\end{array}$ \\
\hline 1. & A & $\begin{array}{c}22.30 \pm 1.14 \\
a\end{array}$ & $\begin{array}{c}1.36 \pm 0.0 \\
2 \mathrm{ab}\end{array}$ & $\begin{array}{c}49.0 \pm 2.8 \\
2 \mathrm{ab}\end{array}$ & $\begin{array}{c}24.34 \pm 0 \\
10 a\end{array}$ & $\begin{array}{c}44.28 \pm 0 \\
10 c\end{array}$ & $\begin{array}{c}31.42 \pm 0 \\
19 d\end{array}$ & Clay loam. \\
\hline 2. & B & $\begin{array}{c}28.91 \pm 0.21 \\
b\end{array}$ & $\begin{array}{c}1.27 \pm 0.1 \\
1 \mathrm{a}\end{array}$ & $\begin{array}{c}52.0 \pm 1.4 \\
1 \mathrm{a}\end{array}$ & $\begin{array}{c}29.30 \pm 0 \\
15 b\end{array}$ & $\begin{array}{c}47.00 \pm 0 \\
01 d\end{array}$ & $\begin{array}{c}23.70 \pm 0 \\
14 b\end{array}$ & Silty loam \\
\hline 3. & C & $\begin{array}{c}23.12 \pm 0.09 \\
a\end{array}$ & $\begin{array}{c}1.55 \pm 0.1 \\
1 b\end{array}$ & $\begin{array}{c}41.5 \pm 0.7 \\
c\end{array}$ & $\begin{array}{c}38.80 \pm 0 \\
16 c\end{array}$ & $\begin{array}{c}30.50 \pm 0 \\
19 b\end{array}$ & $\begin{array}{c}30.70 \pm 0 \\
56 \mathrm{~d}\end{array}$ & Sandy-loam \\
\hline 4. & D & $\begin{array}{c}23.88 \pm 0.24 \\
a\end{array}$ & $\begin{array}{c}1.46 \pm 0.0 \\
9 a b\end{array}$ & $\begin{array}{c}45.0 \pm 2.8 \\
2 b c\end{array}$ & $\begin{array}{c}59.80 \pm 1 \\
38 d\end{array}$ & $\begin{array}{c}13.00 \pm 0 \\
71 \mathrm{a}\end{array}$ & $\begin{array}{c}27.20 \pm 0 . \\
64 c\end{array}$ & Sandy clay loam \\
\hline 5. & E & $\begin{array}{c}23.91 \pm 0.21 \\
a\end{array}$ & $\begin{array}{c}1.54 \pm 0.0 \\
5 b\end{array}$ & $\begin{array}{c}42.0 \pm 1.4 \\
0 c\end{array}$ & $\begin{array}{c}69.44 \pm 0 \\
44 \mathrm{e}\end{array}$ & $\begin{array}{c}11.00 \pm 1 \\
0 \mathrm{a}\end{array}$ & $\begin{array}{c}19.56 \pm 0 \\
10 a\end{array}$ & Sandy loam \\
\hline & $\begin{array}{l}. . S . D . \\
<0.05)\end{array}$ & 1.91 & 0.23 & 5.21 & 2.39 & 2.03 & 1.45 & ---- \\
\hline
\end{tabular}


Table 2 (b). Chemical characteristics of different soil

\begin{tabular}{|c|c|c|c|c|c|c|c|c|c|c|}
\hline \multirow{2}{*}{$\begin{array}{l}\text { Local } \\
\text { ity }\end{array}$} & \multirow{2}{*}{$\begin{array}{c}\mathrm{CaCO}_{3} \\
{[\%]}\end{array}$} & \multirow{2}{*}{$\begin{array}{c}\mathrm{Cl} \\
{\left[\mathrm{mgL}^{-1}\right]}\end{array}$} & \multirow[t]{2}{*}{ pH } & \multirow{2}{*}{$\begin{array}{l}\text { O.M. } \\
\text { [\%] }\end{array}$} & \multirow{2}{*}{$\begin{array}{c}\text { T.O.C. } \\
\text { [g] }\end{array}$} & \multirow{2}{*}{$\begin{array}{c}S \\
{\left[\mu g^{-1}\right]}\end{array}$} & \multirow{2}{*}{$\begin{array}{c}\text { E.C. } \\
{\left[\mathrm{dScm}{ }^{-1}\right]}\end{array}$} & \multirow{2}{*}{$\begin{array}{c}\text { T.D.S. } \\
{\left[\mathrm{mgL}^{-1}\right]}\end{array}$} & \multicolumn{2}{|c|}{ Exchangeable } \\
\hline & & & & & & & & & $\begin{array}{c}\mathrm{Na} \\
{[\mathrm{ppm}]}\end{array}$ & $\begin{array}{c}\text { K } \\
\text { [ppm } \\
\text { ] }\end{array}$ \\
\hline A & $\begin{array}{c}21.60 \pm 1 \\
2 b\end{array}$ & $00 \pm 0.0 a$ & $\begin{array}{c}7.00 \pm 0.1 \\
5 b\end{array}$ & $\begin{array}{c}4.50 \pm 0.2 \\
8 a\end{array}$ & $\begin{array}{c}2.61 \pm 0 . \\
03 e\end{array}$ & $\begin{array}{c}58.75 \pm 2 \\
86 b\end{array}$ & $\begin{array}{c}19.00 \pm 0 \\
3 d\end{array}$ & $\begin{array}{c}13.90 \pm 0 \\
.7 d\end{array}$ & $\begin{array}{c}190 \pm 1 \\
0 b\end{array}$ & $\begin{array}{c}156 \pm \\
4 b\end{array}$ \\
\hline B & $\begin{array}{c}31.65 \pm 0 \\
27 c\end{array}$ & $00 \pm 0.0 a$ & $\begin{array}{c}6.54 \pm 0.0 \\
6 a\end{array}$ & $\begin{array}{c}7.56 \pm 0.1 \\
0 b\end{array}$ & $\begin{array}{c}4.38 \pm 0 \\
02 d\end{array}$ & $\begin{array}{c}41.25 \pm 0 \\
12 a\end{array}$ & $\begin{array}{c}33.20 \pm 0 . \\
6 \mathrm{e}\end{array}$ & $\begin{array}{c}24.50 \pm 0 \\
.3 e\end{array}$ & $\begin{array}{c}410 \pm 1 \\
0 c\end{array}$ & $\begin{array}{c}162 \pm \\
6 b\end{array}$ \\
\hline C & $\begin{array}{c}14.15 \pm 0 . \\
31 a\end{array}$ & $400 \pm 10 c$ & $\begin{array}{c}6.81 \pm 0.0 \\
5 a b\end{array}$ & $\begin{array}{c}3.23 \pm 0.1 \\
2 a\end{array}$ & $\begin{array}{c}1.87 \pm 0 \\
04 c\end{array}$ & $\begin{array}{c}40.00 \pm 3 \\
0 a\end{array}$ & $\begin{array}{c}7.20 \pm 0.3 \\
0 \mathrm{~b}\end{array}$ & $\begin{array}{c}5.20 \pm 0 \\
30 \mathrm{~b}\end{array}$ & $\begin{array}{c}650 \pm 1 \\
0 e\end{array}$ & $\begin{array}{c}197 \pm \\
6 c\end{array}$ \\
\hline D & $\begin{array}{c}19.75 \pm 0 \\
09 b\end{array}$ & $\begin{array}{c}710 \pm 25 \\
d\end{array}$ & $\begin{array}{c}6.66 \pm 0.0 \\
3 a\end{array}$ & $\begin{array}{c}3.26 \pm 0.0 \\
9 a\end{array}$ & $\begin{array}{c}1.89 \pm 0 \\
01 \mathrm{a}\end{array}$ & $\begin{array}{c}45.00 \pm 3 \\
0 a\end{array}$ & $\begin{array}{c}9.60 \pm 0.2 \\
0 \mathrm{c}\end{array}$ & $\begin{array}{c}7.10 \pm 0 \\
10 c\end{array}$ & $\begin{array}{c}567 \pm 7 \\
\text { Od }\end{array}$ & $\begin{array}{c}207 \pm \\
8 c\end{array}$ \\
\hline E & $\begin{array}{c}19.55 \pm 0 \\
18 b\end{array}$ & $\begin{array}{c}140 \pm 5.0 \\
b\end{array}$ & $\begin{array}{c}7.65 \pm 0.0 \\
6 c\end{array}$ & $\begin{array}{c}3.42 \pm 0.0 \\
8 a\end{array}$ & $\begin{array}{c}1.98 \pm 0 \\
01 b\end{array}$ & $\begin{array}{c}125.00 \pm 4 \\
.0 \mathrm{c}\end{array}$ & $\begin{array}{c}0.80 \pm 0.1 \\
0 a\end{array}$ & $\begin{array}{c}0.60 \pm 0 \\
10 a\end{array}$ & $\begin{array}{c}113 \pm 7 . \\
0 a\end{array}$ & $\begin{array}{c}74 \pm 6 \\
a\end{array}$ \\
\hline $\begin{array}{c}\text { L.S.D. } \\
(p<0.0 \\
5)\end{array}$ & 2.08 & 44.52 & 0.30 & 0.56 & 0.09 & 10.56 & 1.25 & 1.35 & 32.43 & 22.29 \\
\hline
\end{tabular}

Sites: $\mathbf{A}=$ Karachi University Campus; $\mathbf{B}=$ Indus Battery factory; $\mathbf{C}=$ Universal Chemicals factory;

$\mathbf{D}=$ Haroon Textile factory; $\quad \mathbf{E}=$ National Foods Ltd. factory

Abbreviation and symbol used: $\mathrm{CaCO}_{3}=$ Calcium Carbonate; $\mathrm{Cl}=$ Chloride; $\mathbf{p H}=$ Power of Hydrogen ion; O.M. = Organic Matter; T.O.C. = Total Organic Carbon; S = Sulphur; E.C. = Electrical Conductivity; T.D.S. $=$ Total Dissolved Salts; $\mathbf{N a}=$ Sodium; $\mathbf{K}=$ Potassium

Numbers followed by the same letter in the same column are not significantly different according to Duncan Multiple Range Test at $p<0.05$ level. \pm Standard Error, L.S.D. Least Significant Difference
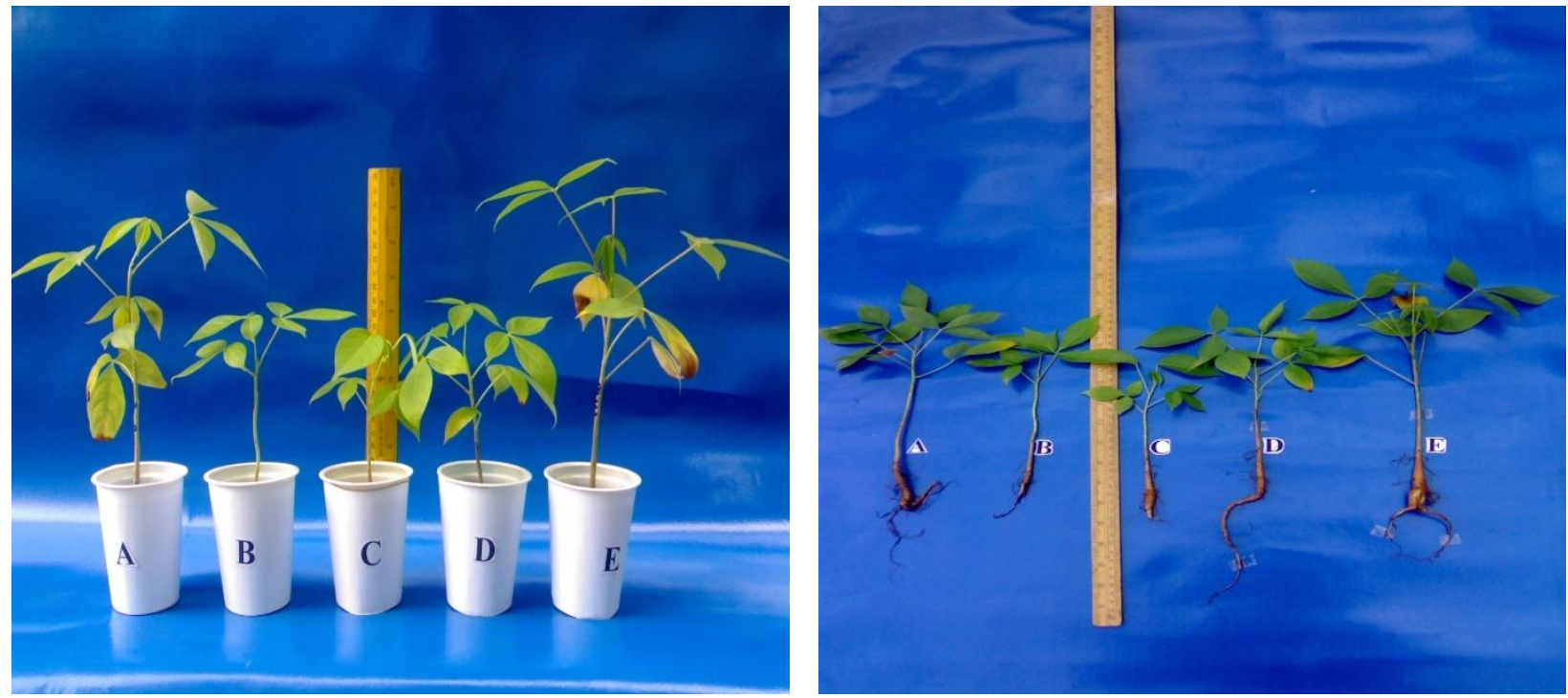

Figure. 1, Seedling growth of $C$. fistula in different samples of University Campus and industrial polluted soils 
Sites $\quad \mathbf{A}=$ Karachi University Campus soil

B $=$ Indus Battery factory soil

C = Universal Chemicals factory soil

D = Haroon Textile factory soil

$\mathbf{E}=$ National Foods Ltd. factory soil

\section{References}

1. Mir, M.A. 2018. Global Warming: An Evolutionary Protective Factor Upon Earth. Journal of Pollution, Volume 1, pp. 1-2

2. Kabir, M., Iqbal, M.Z., 2011. Effects of different soils on seedling growth of Cassia fistula L. under natural field conditions. FUUAST Journal of Biology, Volume 1, pp. 115-122

3. Rehman, S.A., Iqbal, M.Z. 2009. Growth of Leucaena leucocephala (Lam.) De-wit in different soil compositions of Korangi and Landhi industrial areas of Karachi, Pakistan. Pakistan Journal of Botany, Volume 41, pp. 3125-3138

4. Kabir, M. 2014. Effects of industrial pollution on tolerance and distribution of plants". Ph.D. thesis. University of Karachi, Karachi, Pakistan

5. Dutta, R.K., Agrawal, M. 2002. Effect of tree plantations on the soil characteristics and microbial activity of coal mine spoil land. Tropical Ecology, Volume 43, pp. 315-324 